\title{
A REKLÁMTEVÉKENYSÉG ÉS A PIACI SZERKEZET NÉHÁNY ÖSSZEFÜGGÉSE
}

A gazdaságok, illetve a piacok fejlódésével megjelentek és egyre fontosabbá váltak a verseny más típusú eszközei. Ezek közé tartozik a reklám, a termékdifferenciálás, továbbá még olyan testetlen javak, mint a kutatás-fejlesztés, a know-how és a márka. Ezen eszközöknek az alkalmazása lényegesen összetettebb és bonyolultabb feladat, továbbá a fogyasztókra, a versenytársakra és magára a versenyre gyakorolt hatása sokkal nehezebben előre jelezhetố, meghatározható és modellezhetố. A szerzó jelen munkájában a reklámokkal foglalkozik. Tanulmányának célja a reklámtevékenység és a verseny fontosabb összefüggéseinek ismertetése és elemzése, valamint rámutat arra, hogyan alakul a reklám szerepe, jellege, pénzbeli mértéke és hatása a különbözó piaci szerkezetek esetén.

Kulcsszavak: reklám, piaci verseny, reklámköltségek

A reklámozás a potenciális vagy a tényleges fogyasztók felé irányuló kommunikációs tevékenység, amelynek szerepét, jellegét, pénzbeli mértékét és hatását nagyban meghatározza a vállalat versenykörnyezete és a körülvevő piaci szerkezete. Marketingszempontból a reklám a promóciós mix egyik formája, vagyis egy kommunikációs eszköz. A reklámmal foglalkozó marketing-szakirodalom így alapjában véve azzal foglalkozik, hogy milyen reklámprogrammal lehet a célpiacot eredményesen és hatékonyan elérni - a vásárlási készség egyre magasabb szintjének megvalósulása érdekében. Ennek kapcsán tehát az képezi vizsgálat és elemzés tárgyát, hogy a marketingstratégia és a marketingmix többi eleméhez illeszkedóen milyen jellegú és üzenetû́ reklámmal célszerú a fogyasztókat informálni, meggyőzni, és ehhez milyen közvetítő médium megfelelő, továbbá a reklámhatékonyság mérése is ide kapcsolódik.

A vállalatok számos tényezôvel és eszközzel versenyeznek a piacon. A piacelméletben ${ }^{1}$ az ár- és a kibocsátási szinttel való verseny képezi a vállalatok közti versengés alapvető formáját. Ennek jelentőségét mutatják például az oligopólium esetére kidolgozott, különböző feltételrendszerre épülő Bertrand, Cournot és Stackelberg modellek.
A gazdaságok, illetve a piacok fejlődésével megjelentek és egyre fontosabbá váltak a verseny más típusú eszközei. Ezek közé tartozik a reklám és a termékdifferenciálás, továbbá még olyan testetlen javak, mint a kutatás-fejlesztés, a know-how és a márka. Ezen eszközöknek az alkalmazása lényegesen összetettebb és bonyolultabb feladat, továbbá a fogyasztókra, a versenytársakra és magára a versenyre gyakorolt hatása sokkal nehezebben előre jelezhető, meghatározható és modellezhetô. Jelen munkámban közülük csak a reklámokkal foglalkozom. Ehhez kapcsolódóan fontosnak tartom kiemelni Schmalensee (1982) megállapítását, amely szerint a témában megjelent publikációk többsége azt feltételezi, hogy a reklámverseny - valamint a nem árverseny többi formája - gyengébb, mint az árverseny, abban az értelemben, hogy a jövedelemtöbblet kevésbé van veszélynek kitéve. Ez egyben azt is jelentené, hogy a piaci részesedés érzékenyebb az árkülönbségekre, mint a reklámráfordításokban való eltérésekre. Annak ellenére, hogy ez feltehetôen számos piacra jellemző, egyes piacokon azonban, ahol a fogyasztók márkaválasztását erősen befolyásolják a reklámok, az árak pedig csak gyengén, ott várhatóan az árverseny gyengébb a reklámversenyhez képest. 
Közgazdasági szempontból tehát a reklám a verseny nem ár jellegü eszközeinek egyike. E cikkben a reklám fogalmát ez utóbbi értelemben és megközelítésmódban használom. Tanulmányom célja a reklámtevékenység és a verseny fontosabb összefüggéseinek ismertetése és elemzése, valamint rámutatni arra, hogyan alakul a reklám szerepe, jellege, pénzbeli mértéke és hatása a különbözó piaci szerkezetek esetén.

A reklámmal mint a vállalatok közti verseny eszközével nemcsak azért fontos foglalkozni, mert a fejlett piacokon meghatározó szerepe van a keresletgenerálásban, valamint nagyon összetett a hatásmechanizmusa, hanem azért is, mert a reklámráfordítások mértéke, valamint annak növekedése igen jelentôs. A reklám piaci folyamatokban való jelentőségét jól mutatja egyrészról a válság bekövetkezésének hatására történő viszonylag gyors és számottevő mértékú reklámráfordítás viszszaesése, másrészról pedig a reklámberuházások rövid időn belül történő újbóli fellendülése (ZenithOptimedia, 2010).

\section{A reklám és a piaci verseny néhány fontos összefüggése}

A reklámmal foglalkozó korai közgazdasági publikációk szerzôi (Kaldor, 1950/1951; Bain, 1965) összeférhetetlennek tekintették a reklámtevékenységet és a piaci versenyt. A reklám antikompetitív hatása mellett érvelók indoka fóként az volt, hogy a reklámozás eredményeképpen a fogyasztók észlelik a javak közti (valós vagy látszólagos) különbségeket, ezáltal márkahúség alakulhat ki, és ez belépési korlátot jelenthet, vagyis elriaszthatja a potenciális belépóket. Ily módon gyengül a verseny, egyes vállalatok - amelyeknek erôs márkát sikerült létrehozniuk - az értékesítés növelése révén nagyobbakká válnak, és piaci erőfölényre tesznek szert. Mindennek következtében pedig egy koncentráltabb piaci szerkezet alakul ki (Lambin, 1976 hiv. Pearce - Cunningham - Miller, 1971; Pepall - Richards - Norman, 2008). A reklámnak az árral, a minőséggel és az üzletek helyével kapcsolatos információtartalma azonban erósíti a piaci versenyt ${ }^{2}$ (Pepall - Richards Norman, 2008), ezt empirikus vizsgálatok eredményei is bizonyítják (Benham, 1972). Ez azzal magyarázható, hogy a reklám által nyújtott információk következményeként a fogyasztók informáltsága javul, és ezzel a piaci szerkezet jellege közelebb kerül a tökéletes versenyéhez.

Úgy vélték továbbá, hogy a reklámozás belépési korlátot jelent, mivel a piacon már hosszabb ideje múködő vállalatok a reklámtevékenység hatására ismertségre tesznek szert, termékdifferenciálást tudnak megvalósítani, valamint a fogyasztók valamilyen szintú informálását és meggyőzését is képesek elérni. Egy újonnan a piacra belépőnek viszont idôre van szüksége mindennek realizálásához (Chiplin - Sturgess, 1981; Pepall - Richards - Norman, 2008). Spence (1980) szerint továbbá a reklám a méretgazdaságosság mértékének befolyásolásával tud hozzájárulni a belépési korláthoz, hangsúlyozza azonban, hogy a reklám esetében a méretgazdaságosság nehezen megragadható - ellentétben a termelés terén megvalósuló méretgazdaságossággal. A már régebb óta piacon lévô vállalatoknak így tehát bizonyos szempontból és bizonyos mértékig versenyelônyük van egy piacra belépó vállalattal szemben.

Schmalensee (1974) azonban felhívja a figyelmet arra, hogy ha a piacon múködő vállalat reklámtevékenységével nem szerzett előnyt egy újonnan megjelenő vállalathoz képest, akkor a reklám nem jelent belépési korlátot. Annak ellenére sem, ha a piacon már régebb óta múködő vállalat termékeinek megvásárlására tudja késztetni a fogyasztók egy körét. Carlton - Perloff (2003) ehhez hozzáteszi, hogy amennyiben a potenciális belépó úgy véli, hogy reklámja legalább olyan hatásos lesz, mint a már régebb óta a piacon múködő vállalatoké, akkor a verseny e formája miatt nem retten el a piacon való megjelenéstól, vagyis a reklám ez esetben nem tekinthető belépési korlátnak.

Gyakran előfordul továbbá az is, hogy egy új terméket vagy innovációt a piacon elsóként bevezető vállalatnak lényegesen magasabbak a reklámberuházásai, mint egy később belépónek, minthogy az innovatív vállalatnak meg kell ismertetnie az új terméket a fogyasztókkal, és meg is kell győznie azokat az új kínálati elem hasznosságáról. Arról is erôsen megoszlanak továbbá a nézetek, hogy a potenciális belépóket intenzív, valamint túlzott mértékú reklámozással (Dixit, 1980) avagy csekély mértékú reklámráfordítással lehet elrettenteni a piacon való megjelenéstól (Bagwell, 2001).

Sutton (1991) fontos összefüggésekre hívja fel a figyelmet azokban az ágazatokban, ahol a márkák egymástól való megkülönböztetéséhez nagyban hozzájárulnak a reklámok, ott jelentôs a reklámráfordítások mértéke és magas a piaci koncentráció. Úgy véli továbbá, hogy az intenzív reklámozás és a magas piaci koncentráció között akkor a legszorosabb az összefüggés, amikor erôs a piacon az árverseny. Ezt azzal indokolja, hogy a nagy reklámráfordítás valójában elsüllyedt költségnek tekinthetó, és amennyiben ezzel párhuzamosan élénk az árverseny, akkor ez még inkább elrettenti a potenciális belépóket. Az empirikus vizsgálatok azonban nem bizonyítják, hogy a reklám belépési korlátként is hat (Greuner - Kamerschen - Klein, 2000). 
Az 1950-es és 1960-as években megjelent írásmúvek többségében (Kaldor, 1950/1951; Galbraith, 1958) az volt a következtetés, hogy a reklám kedvezótlen hatással van a fogyasztókra. Alapvetóen azért, mert úgy vélték, hogy a reklámozás célja a fogyasztók ízlésének megváltoztatása, valamint a termék, illetve a márka egyediségének tudatosítása annak érdekében, hogy a fogyasztók azt észleljék, hogy a reklámozott jószágnak nincs, vagy csak néhány közeli helyettesítóje lelhetô fel a piacon. Amennyiben a vállalat reklámtevékenységének hatására a potenciális fogyasztók valamekkora hányada vásárol, a vállalat piaci ereje növekszik, a kereslet rugalmatlanabbá válik és kereszt-árrugalmassága csökken. E nézet képviselői hangsúlyozták továbbá, hogy a reklámozás a vállalatnak ugyan többletbevételt eredményez, a fogyasztókat azonban negatívan érinti. Egyrészt a vállalat monopolerejének fokozódása és az ennek következményeként keletkezó holtteher-veszteség végett. Másrészrôl pedig, mert úgy vélték, hogy a vállalatok a reklámozással - a javak közti különbözőség észlelését szeretnék elérni, vagyis - mesterséges termékdifferenciálást hajtanak végre, azaz valójában egyfajta pazarlás történik, és a reklámtevékenység költségét célszerúbb lenne hasznos javak előállítására fordítani (Comanor - Wilson, 1979; Pepall - Richards - Norman, 2008).

A fentiekkel szemben álló nézetet képvisel Telser (1964), aki mérföldkőnek tekinthetố cikkében kétségbe vonta, hogy a reklámtevékenység hatására a vállalat monopolereje fokozódik. Három ágazatban végzett vizsgálatának eredménye alapján arra a következtetésre jutott, hogy az egyes vállalatok piaci részesedésének nagysága annál inkább ingadozó, minél intenzívebb a reklámozás az iparágban. Ez a konklúzió ellentétben van azzal a teóriával, amely szerint a reklám hatására a fogyasztók márkaváltogatása kisebb valószínúséggel következik be, vagy akár márkahúség is kialakulhat, és ezáltal a vállalatok piaci részesedésének mértéke tartósan változatlan marad. Telser kutatásának eredményeivel tehát arra mutatott rá, hogy a reklám befolyásoló hatásának eredményeképpen a fogyasztók kevésbé kötôdnek egy termékhez vagy márkához. Ebból következốen pedig a reklám erôsíti a versenyt. Ezt empirikus vizsgálatok is megerôsítik (Greuner - Kamerschen Klein, 2000; Nayaradou, 2006).

A reklám versenyt fokozó hatását Reekie (1981) azzal magyarázza, hogy a reklámozás által a fogyasztók informáltsága javul a piacon lévő termékekról, és növekszik a vásárlási döntéshozataluk tudatossága, a meggyőző célzatú reklámok továbbá elősegíthetik a fogyasztó számára magasabb hasznosságot nyújtó termékek választását. Amennyiben pedig a reklám a vállalatok közti versengés meghatározó formájává válik, a reklámráfordítások mértéke jelentőssé válhat, és egyfajta pazarló verseny következhet be, amelynek eredményeképpen a vállalatok profitja nem emelkedik (Pepall - Richards - Norman, 2008). Coyte - Landon (1989) empirikus vizsgálatának eredményei szerint minél intenzívebb a piaci verseny, annál többet költ a vállalat reklámra. Ágazatonként az elmúlt mintegy hatvan évet tekintve a reklámráfordítások relatív mértéke viszonylag stabilnak tekinthetô azokban az iparágakban, amelyekben a reklámberuházások nagysága viszonylag magas volt az 1950-es években, ott jelenleg is az (Pepall - Richards - Norman, 2008). Egy profitmaximalizáló vállalat számára az jelenti az optimális reklámmennyiséget, amelynél a reklám határköltsége és határbevétele egyenlôvé válik.

Az újszerúbb piacelméleti megközelítés szerint a reklám a különböző márkákat piacra vivő vállalatok közti verseny fontos tényezóje. Egy ágazatban az intenzív reklámozás pedig aktív piaci múködésre utal. A késóbb kialakuló modern szemléletmód szerint tehát nem a reklámozás hatásának eredményeképpen erósödik egy vállalat piaci ereje, hanem valójában a piaci eró az, ami ösztönzi a reklámtevékenységet (Pepall Richards - Norman, 2008).

Számos kutatást készítettek a reklámtevékenység intenzitása és a piaci koncentráció kapcsolatának vizsgálatára, az eredmények azonban megoszlanak. Mann - Henning - Meehan (1967), Orstein et al. (1973), valamint Strickland - Weiss (1976) szerint a reklámtevékenység erősíti a piaci koncentrációt, Telser (1964, 1969), Ekelund - Maurice (1969) és Ekelund - Gramm (1970) viszont arra a következtetésre jutott, hogy a reklám nem befolyásolja vagy mérsékli a piaci koncentrációt. Ezen összefüggéssel foglalkozó tanulmányokat összességében tekintve az állapítható meg, hogy nem lehet bizonyossággal meghatározni, milyen kapcsolat van a reklámtevékenység és a piaci koncentráció között. Fontos továbbá kiemelni, hogy a reklám és a piaci koncentráció közti ok-okozati összefüggés sem tisztázott. Ennek a magyarázata abban gyökerezik, hogy egyes vélemények szerint nem egyirányú a reklám és a verseny kapcsolata. Reekie (1981) például kiemeli, hogy nemcsak a reklámnak van hatása a versenyre, hanem másrészról a reklám is függvénye a versenynek. Ha ugyanis erős a verseny a piacon, akkor a vállalat számára a reklám a védekezés és a kockázatminimalizálás hatékony eszköze lehet.

Nagyon fontosnak tartom kiemelni azon észrevételemet, hogy a reklám szerepével, hatásával foglalkozó közgazdasági írásmúvekben néhány modern megközelítésú kivételtől eltekintve implicit módon azt feltétele- 
zik, hogy a reklám keresletgeneráló hatása bizonyosan nagy hatékonysággal érvényesül. Ez azt jelenti, hogy többnyire nem számolnak azzal, hogy a potenciális fogyasztók a reklámoknak nem mindegyikét észlelik, valamint hogy nem minden az egyén tudatáig eljutó reklám hoz létre a termék vagy a márka iránt vágyat, illetve eredményez tényleges vásárlást. Meglátásom szerint e mögött alapvetốn az húzódik meg, hogy korábban lényegesen szúkebb volt a piacon a termékkínálat, így kevesebb volt a reklám, következésképpen pedig a fogyasztók jobban odafigyeltek a reklámokra. A fejlett piacok kialakulásával, a tömeggyártással, a termékválaszték bővülésével, a vállalatok közti verseny erôsödésével azonban a reklámok szerepe felerősödött, és mennyisége is jelentősen megnövekedett. A meggyőzố célzatú reklámok számának dinamikus emelkedése következtében a keresletgeneráló hatásuk azonban egy idô után csökkenésnek indult, olyannyira, hogy egy átlagos fogyasztónál a reklámimpulzusok mintegy 90\%-a ma már el sem éri az észlelési küszöböt, és a fogyasztók jelentôs hányada tudatos reklámkerüléssel reagál ${ }^{3}$ a nagymértékú reklámterhelésre (Sas, 2007). A reklámtevékenység hatékonyságának csökkenését fontos lenne tehát integrálni a piacelméleti összefüggésekbe, modellekbe, és ezt figyelembe véve vizsgálni a reklám versennyel és piaci szerkezettel való összefüggéseit.

\section{A reklám és a piaci szerkezet kapcsolata}

A reklám és a piaci szerkezet között - ahogy az a fentiekben leírtakból is következik - feltételezhetôen nem egyirányú a kapcsolat. Ez azt jelenti, hogy nemcsak a piac szerkezete határozza meg a reklám szerepét, típusát, valamint a reklámberuházások mértékét, hanem a reklám is befolyással van a versenykörnyezet és a piaci struktúra alakulására. Schmalensee (1982) szerint a termékjellemzók, a reklám jellege és a fogyasztói informáltság egyaránt befolyásolja, hogy a piaci szerkezetre a reklám milyen hatást gyakorol. A következókben az alapvetố piaci formák, vagyis a tökéletes verseny, a monopólium, az oligopólium és a monopolisztikus verseny esetén mutatom be a reklámtevékenység jellegét, szerepét és hatását.

\section{A reklám és a tökéletes verseny}

A tökéletes verseny jellemzőiból következóen $e$ piaci forma esetén a reklám szükségtelen eszköznek tekinthetô, minthogy például homogének a termékek, és minden fogyasztó rendelkezik minden releváns piaci információval - az árakkal, a termékjellemzókkel és a minőséggel kapcsolatban. A reklámba beruházó vállalat emiatt nem érhet el a versenytársainál nagyobb hasznot (Harvey - Jowsey 2007; Braithwaite 1928). A piaci verseny így az árversenyre korlátozódik (Lambin, 1976).

A versenypiaci feltételek és összefüggések alapján felesleges a reklámtevékenység. Az újszerúbb megközelítés viszont rámutat arra, hogy a tökéletes verseny modellje nem veszi számításba azt, hogy az értékesítésnek is vannak költségei. Az árelfogadóként múködő vállalatoknak is szükségük lehet azonban arra, hogy informálják (potenciális) fogyasztóikat üzletük helyéról, a reklámozás tehát e tekintetben nem összeegyeztethetetlen e piaci struktúrával (Carlton - Perloff, 2003).

Telser (1964) rámutat arra, hogy a termékról és az eladóról információt közvetítő reklámoknak van szerepe és jelentôsége tökéletes versenypiaci körülmények között, vagyis e piaci szerkezet szempontjából nem zárja ki ezen eszköz létjogosultságát. A vásárlók ugyanis nem tudnának az egyes vállalatok múködéséról, ha azok nem reklámoznának. E piaci szerkezet esetében a vállalatok nem tudják befolyásolni az árat, azonban ennek mégis olyan magasnak kell lennie, hogy fedezni tudja a reklámtevékenység költségeit. Telser kiemeli továbbá, hogy mivel az egyes vállalatok azonos információkat nyújtanak a reklámjaikkal a homogén termékekból és az árelfogadásból kifolyólag egyikük sem tud versenyelónyt szerezni a fogyasztók felé történó kommunikációval, így tehát a reklámtevékenység nem gyengíti a versenyt.

Tökéletes verseny esetén ha egy vállalat reklámoz, akkor - minthogy a vállalatok homogén termékeket kínálnak - a teljes piaci kereslet növekszik, és ezáltal a piacon múködő összes vállalat többletbevételhez jut. Az a vállalat azonban, amely a reklámozást végzi, relatíve rosszabbul jár a versenytársaihoz képest, mivel a reklámozás költségei terhelik, és így alacsonyabb profitot tud csak realizálni, mint a versenytársai, és mint ha nem reklámozott volna, de egy másik vállalat igen. Ebben a helyzetben valójában egy ún. „potyautas” jelenség következik be, mert a reklámtevékenységet nem folytató vállalatok jószág iránti kereslete egy másik vállalat reklámozása következtében növekszik meg, valójában tehát anélkül, hogy a vállalat bármilyen pótlólagos erőfeszítést tett volna a kereslet mértékének magasabb szintre emeléséért. Ebból adódóan nem motiváltak a vállalatok a saját maguk által megvalósított reklámozásra, hiszen ez hátrányosan érintené óket a versenytársaikhoz képest, annál kevésbé érdekeltek a reklámozásban, minél nagyobb a piacon múködő vállalatok száma. A tökéletes versennyel jellemezhető piacokon tehát alacsony mértékú reklámozás valószínúsíthetô. Lehetséges továbbá, hogy a vállalatok együttmúködést valósítanak meg a reklámozás terén (Pepall - Richards 
- Norman, 2008), ez jellemzó például akkor, ha valamilyen társadalmi célú, például egészséges élelmiszerek fogyasztásának fontosságát kommunikáló reklámozás történik. Amennyiben a vállalatok kooperálnak a reklámozás terén, a „potyautassá válás” megakadályozható (Pepall - Richards - Norman, 2008).

Minthogy a tiszta versenykörnyezetben múködő vállalatokról feltételezzük, hogy profitmaximalizálásra törekszenek, a reklámtevékenység optimális mértéke annál a ráfordítási szintnél lesz, ahol a reklámozás marginális költsége annak marginális bevételével egyenlóvé válik. Saleh - Mualla (2001) azonban a reklámráfordítások optimalizálásához kapcsolódó közgazdasági levezetés során rámutat arra, hogy tökéletes verseny esetén a vállalat optimális reklámráfordítása zérussal egyenlő, ezt alapvetóen a tökéletesen rugalmas keresleti görbe, valamint a piaci szereplóket jellemzố tökéletes informáltság magyarázza. Ezzel pedig visszatértünk az eredeti, kiinduló állásponthoz, amely szerint e piaci struktúrában a reklám szükségtelen versenyeszköz.

\section{A reklám és a monopólium}

A másik szélsőséges piaci szerkezet a monopólium, amikor egy vállalat alkotja a piac kínálati oldalát, ekkor nem beszélhetünk piaci versenyról. Ebból következóen pedig a reklám nem tekinthetó a verseny eszközének, hacsak nem implicit módon, hogy elrettentse a potenciális belépóket. A meggyőző reklámozásnak e piaci szerkezet esetében kissé eltérő a szerepe a versenykörnyezetben való alkalmazástól, mivel nem a jószág egyediségére és a helyettesítóitól való megkülönböztetésre kell helyezni a hangsúlyt, hanem sokkal inkább azt kell elérnie a vállalatnak, hogy a fogyasztók részérôl igényt keltsen a termék iránt.

Monopolpiaci struktúra esetén a fogyasztók által keresett jószágmennyiség nemcsak annak árától, hanem a vállalat reklámtevékenységétól is függ. A monopolista vállalatnak az a célja a reklámozással, hogy az általa kínált jószág iránti negatív meredekségú keresleti görbe jobbra tolódjon. Arra törekszik tehát, hogy a fogyasztók egy bizonyos áron nagyobb mennyiséget vásároljanak termékéból, vagy ugyanazon jószágmennyiséget magasabb áron is megvásárolják, avagy az értékesítési ár és az eladott jószágmennyiség egyaránt növekedjen. $\mathrm{Az}$ is előfordulhat azonban, hogy a reklámozás hatására az új keresleti görbe olyannyira rugalmatlan lesz, hogy a monopolista vállalat optimális kibocsátási szintje kisebb lesz, mint a reklámozást megelózóen (Dixit - Norman, 1978).

A Dorfman - Steiner (1954) feltétel alapján a monopolista vállalat számára az jelenti az optimális reklámmennyiséget, amelynél a reklámráfordítás és az ér- tékesítés aránya megegyezik a kereslet reklámtól függő rugalmasságának és az árrugalmasságnak az arányával. Ez az alábbi összefüggéssel írható fel:

ahol

$$
\frac{a \times c_{a}}{P \times Q}=\frac{\varepsilon_{a}}{\varepsilon_{P}}
$$

$a$ a reklámüzenetek mennyisége - amely kifejezhetô a rádió- és televízióreklámoknál másodpercben, a sajtóreklámok esetében pedig az elfoglalt hely nagyságával,

$c_{a}$ egységnyi reklám költsége a vállalat számára,

$P$ a jószág ára,

$Q$ a jószág keresett mennyisége,

$\varepsilon_{a}$ a kereslet reklámtól függó rugalmassága,

$\varepsilon_{P}$ a kereslet árrugalmassága.

Ez tehát azt jelenti, hogy a vállalatnak addig optimális növelni a reklámtevékenységét, amíg a reklámberuházások és az értékesités pénzbeli értékének hányadosa egyenló lesz a kereslet reklámtól függó rugalmasságának és az árrugalmasságnak az arányával. $\mathrm{Az}$ összefüggés szerint minél árrugalmatlanabb a kereslet, vagyis minél kisebb az értéke, a vállalatnak annál nagyobb mértékú reklámberuházásra van szüksége, másrészról pedig minél nagyobb a kereslet reklámtól függő rugalmassága, vagyis $\varepsilon_{a}$ értéke, annál nagyobb összeget kell a vállalatnak reklámra fordítania.

A Dorfman - Steiner feltételból továbbá az következik, hogy ha a jószág iránti kereslet árrugalmassága kicsi, akkor a piacon múködő vállalatok viszonylag sokat fordítanak reklámozásra, továbbá pedig minél nagyobb egy vállalatmonopol ereje, annál többet költ reklámozásra. Ezen összefüggés arra utal, hogy nem a reklám hatására erốsödik meg egy vállalat piaci ereje, hanem valójában a piaci eró az, aminek következtében a vállalat reklámráfordításának mértéke jelentôssé válik (Pepall - Richards - Norman, 2008).

Nagyon fontos továbbá rámutatni a termékdifferenciálás foka és a reklámráfordítás mértéke közti viszonyra, amely a fenti összefüggéssel is kapcsolatban áll. Amikor homogén termékek vagy egymáshoz nagyon hasonló javak vannak jelen a piacon, akkor a kereslet árrugalmassága végtelen, illetve rendkívül nagy, és így a keresleti görbe horizontális - mint tökéletes verseny esetén - vagy kis meredekségú lesz. Minél erősebben érvényesül azonban a termékdifferenciálás, a keresleti görbe annál meredekebbé válik. Minthogy a monopolista vállalat egyedi vagy erósen differenciált termékkel van jelen a piacon, keresleti görbéje meredek, közelít a vertikálishoz. Ez egyben azt is jelenti, hogy a jószág keresletének árrugalmassága kicsi, amely egyúttal öszszefüggésben áll azzal is, hogy nincsenek közeli he- 
lyettesítői. Ebben az esetben pedig könnyebben el lehet érni a fogyasztókat a reklámmal, hiszen nincsenek hasonló termékek, illetve versenytársak a piacon; ez tehát azt jelenti, hogy a reklám hatására a fogyasztók által keresett jószágmennyiség jelentősen növekszik, vagyis a kereslet reklámtól függó rugalmassága nagy, és mindebból következóen a monopolista vállalatok reklámráfordítása viszonylag magas. A monopolista vállalat azonban azt a reklámberuházási szintet választja, amellyel maximalizálhatja profitját.

\section{A reklám és az oligopólium}

Az oligopólium az a piaci szerkezet, ahol a reklámnak mint versenyeszköznek rendkívül fontos szerepe van, különösen, ha a piacon múködő vállalatok differenciált termékeket kínálnak a fogyasztók számára. $\mathrm{Ha}$ a vállalatok által bevezetett termékek nem homogének, hanem egyedi jellemzókkel rendelkeznek, akkor a reklámok információtartalma jelentốsen támogathatja a termékek versenytársakétól való megkülönböztetését. Amennyiben pedig egy vállalat meggyôző célzatú reklámot (is) alkalmaz, akkor ennek még nagyobb hatása van a márkaválasztásra, valamint a márkahúség kialakulására. Az oligopóliumot alkotó vállalatok így hajlamosak viszonylag jelentős összegeket reklámberuházásra fordítani. Mindebból következóen pedig elsôsorban az oligopólium az a piaci forma, amely esetén a reklámráfordítások mértéke igen magas, és növekedési üteme számottevô, hiszen ha egy vállalat bôvíti reklámtevékenységét, és versenytársa nem reagál erre a korábbinál intenzívebb reklámozással, akkor alulmaradhat a versenyben.

Amennyiben a vállalatok termékei különböznek egymástól, akkor nem merül fel ,potyautas” probléma. Minden egyes vállalat reklámhatékonyságának megfelelôen realizál többletbevételt. Ez inkább azokon a piacokon valósul meg, amelyeken viszonylag kevés vállalat versenyez, mivel nem egyszerú kiemelkedni, ha sok azonos vagy hasonló igény kielégítésére létrehozott termék található meg a piacon (Pepall - Richards - Norman, 2008).

Chen - Roayaei - Seldon (1993) arra mutat rá, hogy oligopólium esetén a vállalatok reklámtevékenysége externáliákat idéz eló. Negatív externália akkor következik be, amikor a reklámozó vállalat bevételi többlete az ágazatot alkotó többi vállalat hátrányára történik. Pozitív externália pedig akkor valósul meg, ha egy vállalat reklámtevékenységével nemcsak a saját, hanem a piacon múködő többi vállalat értékesítését is növeli. Hangsúlyozzák továbbá, hogy egyes kutatók szerint oligopólium esetén a vállalatok reklámtevékenysége nem növeli az aggregált fogyasztást, az csak a piaci ré- szesedés redisztribúciójához járul hozzá, mások nézete viszont az, hogy az aggregált reklámszint emelkedésével az aggregált fogyasztás is növekszik.

Chiplin - Sturgess (1981) a Dorfman-Steinerfeltételból indul ki, és a feltételrendszert azzal egészíti ki, hogy oligopólium esetén a vállalatnak azt is figyelembe kell vennie, hogyan reagálnak versenytársai a reklámtevékenységére. Modellje alapján arra a következtetésre jut, hogy

- ha a vállalat reklámráfordításának változása hatására annak versenytársai nem változtatják reklámköltségük mértékét, akkor az eredeti Dorfman - Steiner-feltétel érvényesül, és a vállalatok döntéshozatala úgy történik, ahogy a Cournot modellben,

- ha viszont a vállalat reklámberuházásának bóvítése hatására a versenytársak növelik a reklámráfordításuk nagyságát, akkor ennek következtében a vállalat által kínált jószág keresett mennyisége a folyó áron csökken ceteris paribus. Az optimális reklámráfordítás-értékesítés arány így annál magasabb, minél kisebb a versenytársak reklámköltésének várható növekedése.

Fontos dologra hívja fel a figyelmet Simon (1970) duopólium esetén. Ha az egyik vállalat az optimálisnál többet, túl sokat reklámoz, akkor ezáltal csökkenti a másik vállalat reklámhatékonyságát azért, mert több lesz a fogyasztók felé irányuló, termékekkel, márkákkal kapcsolatos kommunikáció. Minél nagyobb továbbá a két vállalat reklámráfordításának mértéke közt a különbség, a csökkenő hozadék elve következtében relatíve annál kevésbé hatékony a reklámozásra nagyobb összeget fordító vállalat reklámtevékenysége. Ezen összefüggésekből eredő hatások feltételezésem szerint többszereplős oligopólium esetében is érvényesülnek valamilyen mértékben, következésképpen pedig a napjainkban érvényesülő reklámhatékonyság-csökkenés egyik fontos okának tekinthetók.

\section{A reklám és a monopolisztikus verseny}

Minthogy monopolisztikus verseny esetén a vállalatok termékei közeli helyettesítók, azonban nem homogének, a reklámnak nagyon lényeges szerepe van a termékek versenytársakétól való megkülönböztetésében, vagyis hogy a fogyasztók észleljék, milyen egyedi jellemzókkel rendelkezik a termék, és miben tér el a piacon megtalálható többi terméktól. E piaci szerkezet esetén tehát nagyon fontos versenyeszköz a reklám, azonban az egyes vállalatok reklámráfordításának mértéke lényegesen kisebb, mint oligopol helyzetben, és mivel sok, kis piaci erôvel rendelkezô vállalat múkö- 
dik a piacon, a kereslet reklámtól függó rugalmassága alacsony. Fontos továbbá, hogy a szakirodalomban a reklámtevékenység szerepére és hatására vonatkozóan e piaci szerkezettel foglalkoznak a legkevesebbet.

A reklám monopolisztikus versenyben való szerepének és hatásának mélyreható elemzésével Chamberlin (1933) foglalkozott elsóként, és teóriája napjainkig meghatározó maradt. Az e piaci struktúrában múködő vállalatok reklámráfordítását „értékesítési költségnek” tekintette. Arra mutatott rá, hogy a reklám árakra gyakorolt nettó hatása tisztán elméleti úton nem határozható meg, mert az egész hatást befolyásolja a reklám informatív jellege vagy meggyőzó ereje, valamint a termelésben és a reklámozásban megvalósuló méretgazdaságosság mértéke (Bagwell, 2001).

\section{Összegzés}

Tanulmányomban a reklámnak mint versenyeszköznek a fontosabb piacelméleti vonatkozásaival foglalkoztam, szakirodalmi áttekintés keretében. Kutatásom eredményeképpen arra a következtetésre jutottam, hogy erósen megoszlanak a nézetek a reklám és a piaci verseny egymásra gyakorolt hatásáról. Fóként e problémakör korai kutatói érveltek amellett, hogy a vállalatok reklámtevékenysége belépési korlátot jelenthet, gyengíti a versenyt és ennek eredményeképpen koncentráltabb piaci szerkezet alakul ki. Az ezzel ellentétes nézetet képviselók szerint a reklámtevékenység erôsíti a vállalatok közti piaci versenyt továbbá ha intenzív a reklámozás egy ágazatban, akkor a vállalatok piaci részesedésének aránya instabil. Egy újszerú megközelítésmód alapján azonban nem a reklámtevékenység eredményeképpen alakul ki a piaci eró, hanem a piaci erő az, amelynek következtében a vállalatok a fogyasztók informálása, meggyőzése céljából reklámoznak. Megállapítható tehát, hogy a reklám és a piaci koncentráció közti okokozati viszony nem megoldott. Felhívtam továbbá a figyelmet arra, hogy fontos lenne a reklámhatékonyság csökkenésének tényét integrálni a reklám piacelméleti vizsgálatába.

A reklám szerepét, jellegét, pénzbeli mértékét és hatását a fóbb piaci formák esetében tekintettem át. Tiszta verseny esetén nincs relevanciája a reklámnak. A monopolista vállalat reklámráfordítása viszont magas (annak ellenére, hogy a reklám ekkor valójában nem tekinthető versenyeszköznek), amely elsősorban az egyedi terméke iránti rugalmatlan keresletnek, valamint a kereslet reklámtól függó nagy rugalmasságának következménye. Átmeneti piaci szerkezet esetén a reklámnak nagy a jelentósége a versenyben, hiszen segíti a differenciált termékek versenytársakétól való megkülönböztethetőségét. Oligopólium esetén fordítanak nagyobb összeget reklámtevékenységre, minthogy ekkor kevesebb vállalat van jelen és magasabb a kereslet reklámtól függó rugalmassága. Meglátásom szerint továbbá ez az a piaci forma, amely elsôdlegesen hozzájárul a reklámráfordítások világszintú növekedéséhez.

\section{Lábjegyzet}

${ }^{1}$ A piacelmélet fogalom alatt az angolul Industrial Organization elnevezésú szakterületet értem.

${ }^{2} \mathrm{Az}$ informatív jellegú reklámozás tipikus példája az, amikor a helyi fogyasztókat az árról és esetlegesen a legfontosabb terméktulajdonságokról, valamint a bolt elhelyezkedéséról informálják a kiskereskedelmi üzletek - ez erôsíti a versenyt, elegendô csak az alapvetóen élelmiszereket és háztartási termékeket forgalmazó szupermarketek reklámtevékenységére gondolni. Fontos ugyanakkor kiemelni, hogy az informatív típusú reklámozás pénzbeli mértéke rendkívül csekély a meggyőző reklámozáséhoz képest, amelyet a nagy termelő cégek a termék- és márkaimázs létrehozása érdekében végeznek (Pepall - Richards - Norman, 2008).

${ }^{3}$ Egy 2004-es hazai felmérés szerint a lakosság 80\%-a aktív és mérsékelt reklámkerülő, és ez a hányad évrôl évre emelkedik (Kaizer, 2006).

\section{Felhasznált irodalom}

Bagwell, K. (2001): The Economics of Advertsing. Introduction. p. 1-20. University of Oklahoma Price College of Business honlapja: http://pcbfaculty. ou.edu/classfiles/MKT\%206773\%20Marketing\%20 Models\%20Basuroy\%20Spring\%202010/wk11/ Bagwell_2001.pdf Letöltés ideje: 2008. február 29.

Bain, J.S. (1965): Barriers to New Competition. Harvard University Press, Cambridge, $\mathrm{M}$

Benham, L. (1972): The Effect of Advertising on the Price of Eyeglasses. Journal of Law and Economics, Vol. 15, No. 2, p. 337-352.

Braithwaite, D. (1928): The Economic Effects of Advertisement. The Economic Journal, Vol. 38, No. 149. p. 16-37.

Carlton, D.W. - Perloff, J.M. (2003): Modern piacelmélet. Panem Kiadó, Budapest

Chamberlin, E. (1933): The Theory of Monopolistic Competition. Harvard University Press, Cambridge, MA Hiv.: Bagwell (2001) p. 2.

Chen, Y. - Roayaei, A.J. - Seldon, B.J. (1993): Cooperative and Predatory Advertising: Effects on Oligopoly Advertising Investment. Atlantic Economic Journal, Vol. 21. No. 2. p. 26-38.

Chiplin, B. - Sturgess, B. (1981): Economics of Advertising. 2nd ed. Holt, Rinehart and Winston: Eastbourne

Comanor, W.S. - Wilson, T.A. (1979): The Effect of Advertising on Competition: A Survey. Journal of Economic Literature, Vol. 17, No. 2, p. 453-476. 
Coyte, P.C. - Landon, S. (1989): The Impact of Competition on Advertising: The Case of Political Campaign Expenditures. Canadian Journal of Economics, Vol. 22, No. 4, p. 795-818.

Dixit, A. (1980): The Role of Investment in Entry-Deterrence. The Economic Journal, Vol. 90, No. 357, p. 95-106.

Dixit, A. - Norman, V. (1978): Advertising and Welfare. The Bell Journal of Economics, Vol. 9. No. 1. p. 1-17.

Dorfman, R. - Steiner, P.O. (1954): Optimal Advertising and Optimal Quality. American Economic Review, Vol. 44, No. 5, p. 826-836.

Ekelund, R.B.-Maurice, C. (1969): AnEmpirical Investigation of Advertising and Concentration: Comment. Journal of Industrial Economics, Vol. 18. No. 1. p. 76-80.

Galbraith, J.K. (1958): The Affluent Society. Mentor, Mentor Greuner, M.R. - Kamerschen, D.R. - Klein, P.G. (2000): The Competitive Effects of Advertising in the U.S. Automobile Industry, 1970-94. International Journal of the Economics of Business, Vol. 7, No. 3, p. 245-261.

Harvey, J. - Jowsey, E. (2007): Modern Economics: An Introduction. 8th ed. Palgrave Macmillan, New York, N.Y.

Kaizer G. (2006): A reklám szép új világa. rekláMérték: Kommunikációelméleti szaklap, Vol. 4, No. 31, Revision Gerillamarketing honlapja: http://www.revision.co.hu/ Letöltés ideje: 2009. március 4.

Kaldor, N. (1950/1951): The Economic Aspects of Advertising. The Review of Economic Studies, Vol. 18. No. 1, p. 1-27.

Lambin, J.J. (1976): Advertising, competition and market conduct in oligopoly over time: An econometric investigation in Western European countries. NorthHolland Publishing Co., Amsterdam

Mann, H.M. - Henning, J.A. - Meehan, J.W. (1967): Advertising and Concentration: An Empirical Investigation. Journal of Industrial Economics, Vol. 16, No. 1, p. 34-45.

Nayaradou, M. (2006): Advertising and Economic Growth. Doctorate thesis in economics, synthesis and principal conclusions drafted by the author. World Federation of Advertisers honlapja: www.wfanet.org Letöltés ideje: 2008. december 28.

Ornstein, S.I. et al. (1973): Determinants of Market Structure. Southern Economic Journal, Vol. 39, No. 4, p. 612-625.
Pearce, M. - Cunningham, S.M. - Miller, A. (1971): Appraising the Economic and Social Effects of Advertising. Marketing Science Institute, Boston

Pepall, L. - Richards, D.J. - Norman, G. (2008): Piacelmélet: Modern megközelítés gyakorlati alkalmazásokkal. HVG-Orac, Budapest

Reekie, W.D. (1981): The Economics of Advertising. The MacMillan Press, London

Saleh, G.A. - Mualla, N. (2001): Optimal Advertising and Market Structure: A Conceptual Framework. Damascus UNIV. Journal, Vol. 17, No. 2, http://www. dahsha.com/up/files/1/ghaleb.pdf Letöltés ideje: 2010. november 23 .

Sas I. (2007): Reklám és pszichológia. Kommunikációs Akadémia, Budapest

Schmalensee, R. (1974): The Economics of Advertising. Humanities Press, New York

Schmalensee, R. (1982): Advertising and Market Structure. Working Paper Alfred P. Sloan School of Management, WP\#1294-82, Massachusetts Institute of Technology. Massachusetts Institute of Technology Libraries honlapja: http://dspace.mit.edu/bitstream/handle/1721.1/46777/ advertisingmarke82schm.pdf?sequence $=1$ Letöltés ideje: 2010. december 15.

Simon, J.L. (1970): Issues in the Economics of Advertising. University of Illinois Press, Urbana

Spence, A.M. (1980): Notes on Advertising, Economies of Scale, and Entry Barriers. The Quarterly Journal of Economics, Vol. 95, No. 3, p. 493-507.

Strickland, A.D. - Weiss, L.W. (1976): Advertising, Concentration, and Price-Cost Margins. Journal of Political Economy, Vol. 84, No. 5, p. 1109-1122.

Sutton, J. (1991): Sunk Costs and Market Structure. MIT Press, Cambridge, MA.

Telser, L.G. (1964): Advertising and Competition. The Journal of Political Economy, Vol. 72, No. 6, p. 537-562.

Telser, L.G. (1969): Another Look at Advertising and Concentration. The Journal of Industrial Economics, Vol. 18, No. 1, p. 85-94.

ZenithOptimedia (2010): Steady recovery in global ad expenditure to continue for at least three years. December 6. ZenithOptimedia honlapja: www.zenithoptimedia. com Letöltés ideje: 2010. december 17. 